\section{Entrepreneurial Community and the Unique Marketing Mix As Social Factors that Create Sense of Place in Lok Baintan Floating Market}

\author{
Astrid Kusumowidagdo*, Dyah Kusuma Wardhani, and Melania Rahadiyanti
}

Interior Architecture Department, Universitas Ciputra, Citraland CBD Boulevard, Surabaya, Indonesia

\begin{abstract}
This study was aimed at exploring the conditions of people with an entrepreneurial spirit or entrepreneurial community, precisely located in Lok Baintan Floating Market. Entrepreneurial community in this Floating Market has a distinctive character which gives color to market existence in term of shaping forming sense of place for the tourism area in Banjarmasin, Borneo. Method used in this study was exploratory qualitative, where the data was obtained from interviewing the head of the local community group, traders, tourists, and local government. The study showed that the Floating Market is distinct not only by its product-based characteristic but also by its service-based in marketing the products, among others, product uniqueness (unique merchandise commodities), price (price and bargaining process), place (located in a river corridor), promotion (a unique way of promotion for both sellers and government support), people (sellers' ethnicity, lifestyle, and speech style), and physical aspect (selling and buying location in a riverboat which is unique and has a memorable impression).
\end{abstract}

Keywords: Sense of place, Entrepreneurial Community, Marketing Mix
Corresponding Author: Astrid Kusumowidagdo astrid@ciputra.ac.id

Received: 30 December 2019 Accepted: 29 January 2020 Published: 6 February 2020

Publishing services provided by Knowledge E

(c) Astrid Kusumowidagdo

et al. This article is distributed under the terms of the Creative Commons Attribution License, which permits unrestricted use and redistribution provided that the original author and source are credited.

Selection and Peer-review under the responsibility of the 6 th ICOEN 2019 Conference Committee.

\section{G OPEN ACCESS}

\section{Introduction}

River is historically significant for Banjarmasin, which is famously known as the city of a thousand rivers. Since the 14th century, the areas of rivers in Banjarmasin have become traffic routes for trading activities, especially during the formation of the Banjar Empire in 1595. At that time, the floating markets were increasingly alive due to transactions with other kingdoms and with sellers or traders from various regions, including the Lok Baintan floating market, which was located just outside Banjarmasin.

In the past, a barter system was used for transaction in floating markets. People still use this system until today, although money is a common tool of payment. The history of trading in this place has been recorded since long time ago. Sheikh Muhammad Arsyad al-Banjari (1710-1812 AD) wrote in his writing, Sabilal Muhtadin, that the seller would call 
out the word "Jual" (sell), and the potential buyer responded with "Tukar" (means that the buyer agreed to buy the goods). Thus, this kind of trade has been going on until now.

Commodities sold in the floating market, among others, are agricultural products, fisheries products, local culinary products and fruits.

The traders are usually in groups and they already exist as a specific community. The group has a leader who will also connect them to the government. The traders also get appropriate from the government. The traders, who mostly are adult women, possess dedication and entrepreneurial spirit which contribute to the distinctiveness of the trading process specifically in the marketing area. Women entrepreneurs in the area will have interdependence on their communities, that both entrepreneurs as individuals and their communities will influence each other in their vision and mission [1]. Togetherness in their community will affect their success as an ecosystem. Furthermore, an entrepreneurial community usually shows characteristics as follows: ability to accommodate multi-frame perspectives, commitment to market orientation, learning together to adapt to the latest conditions (adaptation, and have good solutions for togetherness) [2].

The symbiosis of mutualism appears to be more intertwined all this time. This process provides opportunities for the entrepreneurs to participate, systemic approach, good performance, community as a learning organization, social capital, and infrastructure. However, this interdependency can also change into commensalism (one-sided relationship) or even parasitism (one harms or gets benefits from the other)[2].

Together with their fellow women entrepreneurs in this market, the community has a unique marketing pattern. A complete and naturally occurring marketing mix implementation can also be found in this community. The seven Ps of marketing mix already implemented by the community are in the form of product, price, place, promotion, people, process, and physical evidence.

The uniqueness of this entrepreneurial community, together with its uniqueness marketing methods, must be preserved since this community also contributes in forming an authentic atmosphere, which is the sense of place of the Lok Baintan tourism area which is integrated with the riverside tourism in Banjarmasin [3].

Previous studies, discuss about entrepreneurship communities [2, 4, 5]. Meanwhile, the study on sense of place of a unique marke area as tourism place is already discussed [6]. Integrated marketing mix of the seven Ps in traditional markets has also been carried out in other research [7]. 
The originality of this recent study is in term of exploration and explanation on how an entrepreneurial community of Lok Baintan floating market as a service area might have unique phases of marketing mix in order of preserving the uniqueness of this area's sense of place. The previous research in Korea, try to explore how to improve the tradisional market [8]

\section{Methods and Equipment}

\subsection{Methods}

This study is exploratory qualitative in nature [9]. The data were obtained from in-depth interview. The informants interviewed were from Banjarmasin Tourism Office, leaders of community, and the sellers.

This study followed the rules of marketing mix for service (seven Ps), because in the process of selling not only consists of selling products but also an integrated service process, consisting of product, price, place, promotion, people, process, and physical evidence[10].

\subsection{Research Object}

The object of this study is the entrepreneurial community in Lok Baintan area, described as follows:

1. Entrepreneurial Community.

The entrepreneurial community object is a multi-perspective, proactive, and reflectiveness society that is able to combine old efforts with innovative new efforts, is the community of women entrepreneurs in the Lok Baintan region, Borneo [2, 3]. Lok Baintan.

2. Lok Baintan is a part of Martapura River.

The Lok Baintan floating market has operational time from 3 A.M. to 9.30 A.M. Visitors can come to this market by riverboat or by road. Visiting the market by riverboat surely will offer special experience of space, influenced by the river ripples that will shake up the trading activities which take place on it. Activities centered on and around this brownish Martapura River have started in the morning, such as selling goods, washing their clothes, using the river water in cooking, and even brushing their teeth. 


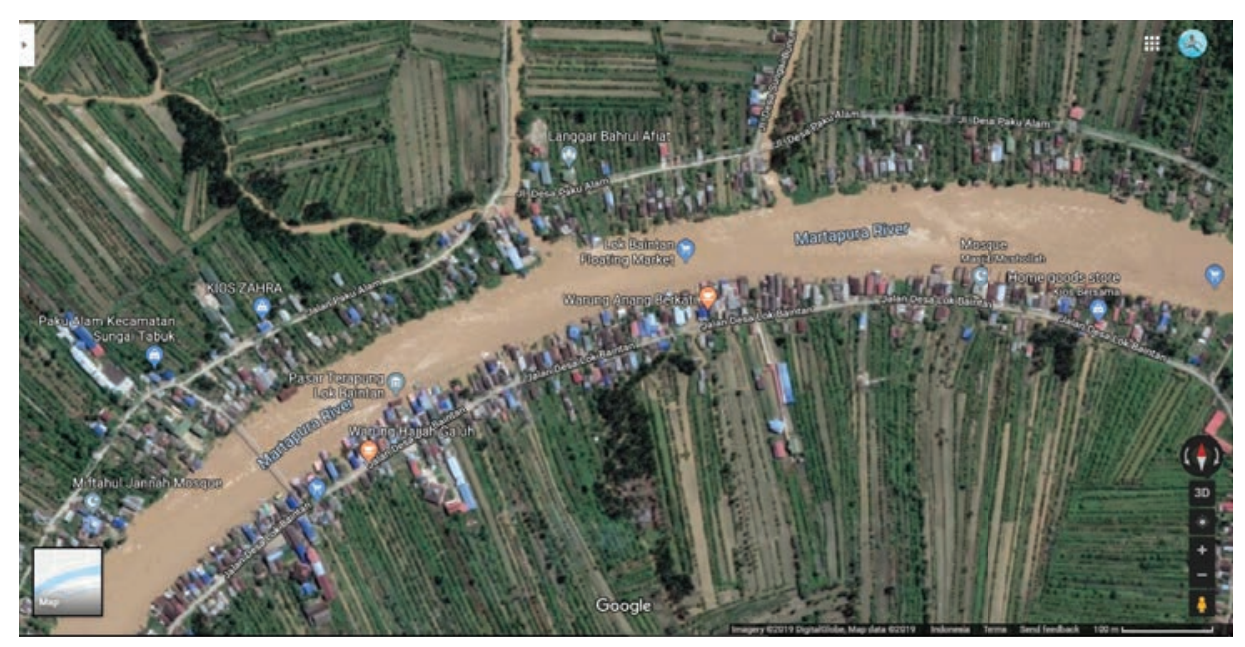

Figure 1: Lok Baintan Floating Market Area seen from aerial imagery (source: Google Maps).

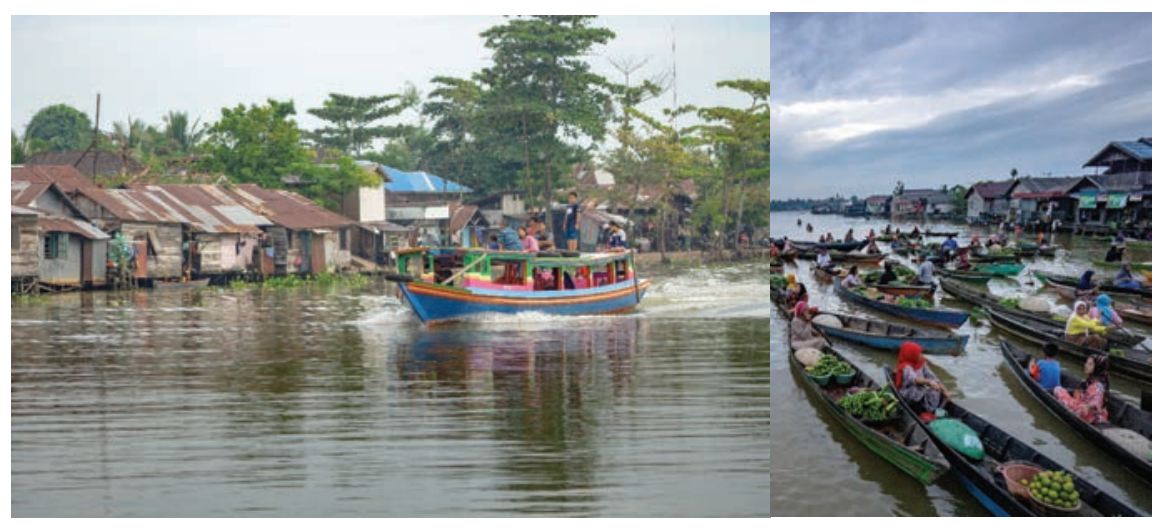

Figure 2: Trade and transportation activities carried out by Lok Baintan residents on the Martapura River. (Source: private photos).

\section{Results}

The results of in-depth observations and interviews showed that the visible marketing mix found in the entrepreneurial community marketing process at Lok Baintan is as follows:

\subsection{Product}

Variants of the products sold in the market are handicrafts, fresh products, fishery products and local culinary products.

In the area of the motorboat, women traders usually use baskets made from purun (a type of grass) to place selling products such as household-made handicraft products, fresh products (vegetables and fruits), as well as local food and pastry products. 
Sometimes, for selling daily food like Soto Banjar and satay, the traders divide the area into preparation area, cooking area, and serving area. They use brazier and also a mini gas stove in order to heat their food to sell.

For packaging, the traders still use woven bag from purun to give the impression of local and traditional product.

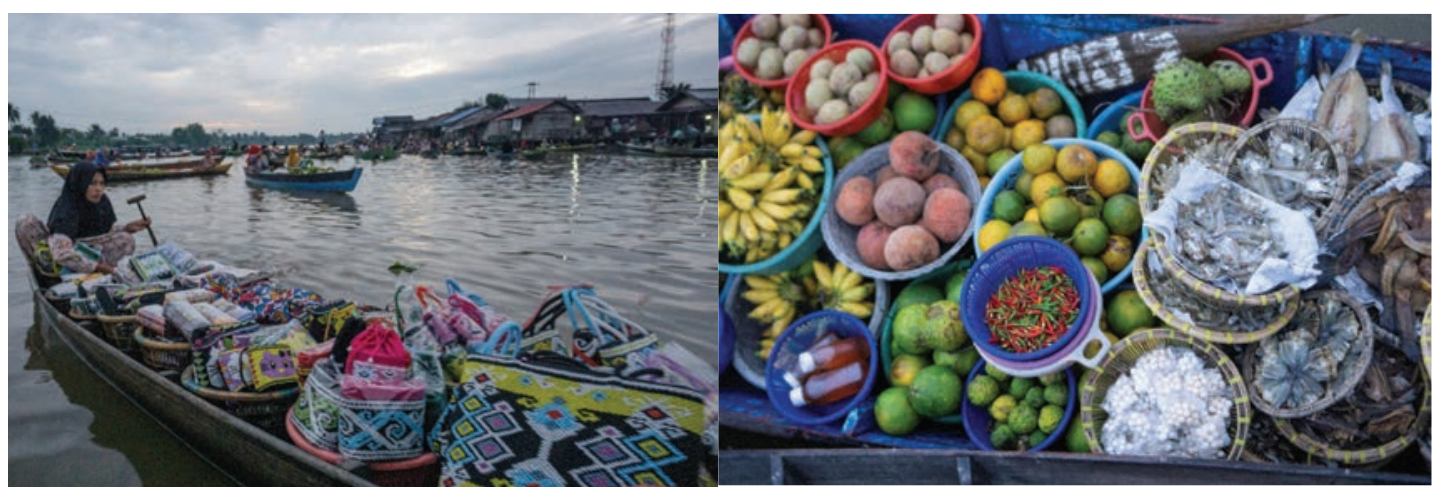

Figure 3: Product variants in the form of handicrafts (left) and fresh products, such as fruits and fish (right). Source: private photos.

\subsection{Place}

The Lok Baintan floating market is located in Lok Baintan village. Its location, which is in the rural area, has a calm atmosphere and natural view, making it differs from other floating market in Muara Kuin which is surrounded by wood industry center, and from The Siring Floating Market in Banjarmasin, which is located in Tabuk River as also a part of the Martapura River.

The river as a place where floating market takes place is the center of live for the villagers. They carry out their daily activities in the river such as cooking, eating, bathing, and washing their clothes. Houses built around the river are stilt houses.

In addition to that, the river is also a main transportation facility. Until now, although river culture slowly changes into land culture, people's moving and trading activities are still centered on the river.

\subsection{Price}

The price for products sold in the floating marketing is quite varied, either for handicraft, fresh products, fishery products or local culinary products. For handicrafts, it ranges from 20,000 rupiah to 100,000 rupiah. For dry and fresh fishery products, the price ranges from 25,000 to 150.000 also depends on the amount of the products 


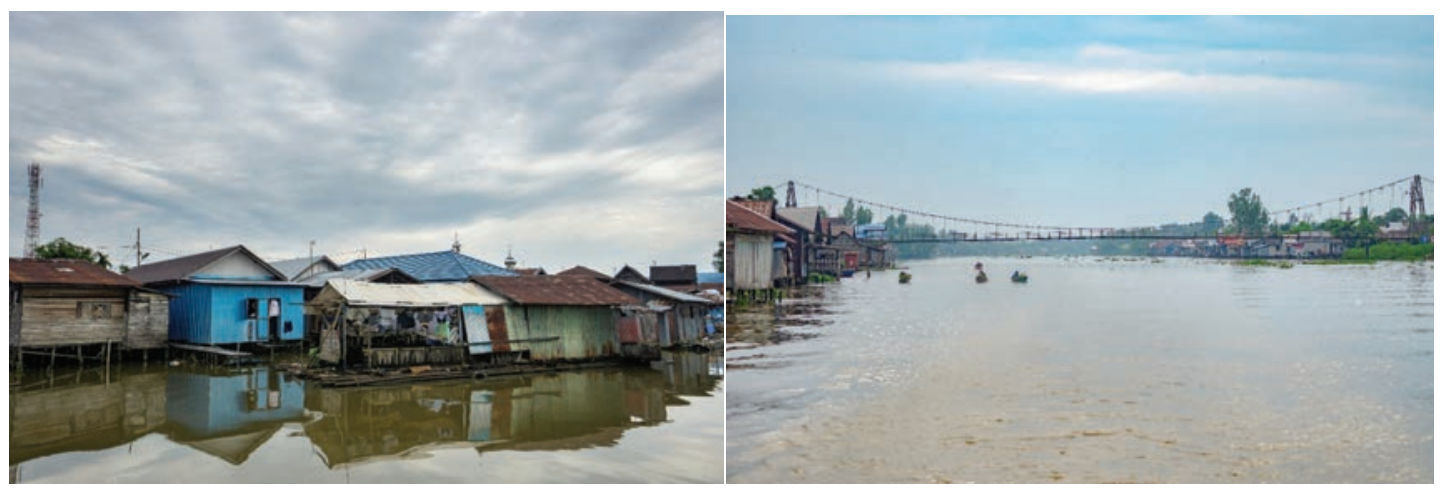

Figure 4: Martapura River, the center of activity and the main transportation route for the residents of Lok Baintan Village. Source: private photos.

bought. Meanwhile, for local culinary products, we can get satay or Soto Banjar with tea and water mineral for only 10,000 rupiahs to 25,000 rupiahs.

The price fluctuates depends on how many buyers or visitors come to the market at the time. Friendship discounts are often given by the traders. Friendly society and the long-used bargaining system make visitors feel that the price offered is reasonable enough.

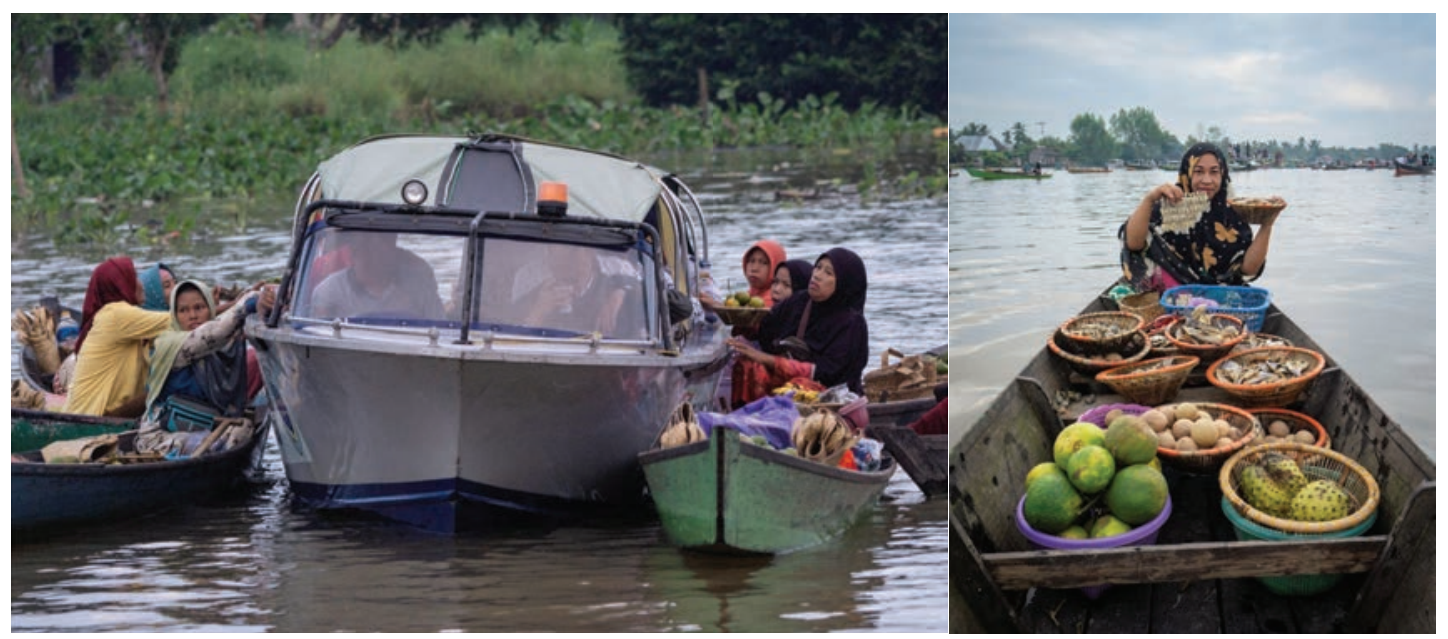

Figure 5: Friendly traders who maintain a bargaining system in determining the selling price of their merchandise. Source: private photos.

\subsection{Promotion}

There are several aspects in the promotion: promotion carried out by the traders themselves; promotion by the visitors; and promotion by the manager or the local government, especially the Banjarmasin Tourism Office. 
Promotion carried out by the traders takes form in word of mouth, offering discount, and offering providing other facilities (such as riding their motorboat). One of the community leaders, Amang Arul, manages a social media account which is used as a force for this unique trading area [3].

Promotion done by the visitors is usually in form of photographs, social media and also content in various blogs that have become a means of communication today. Often, the visitors are YouTube influencers, people of printed media, and people from national even international TV channels.

Furthermore, promotion done by the local government, the Banjarmasin Tourism Office, is in form of having several events to enliven the market. The government also provides rowboats for those who want to visit Lok Baintan, which takes at least one hour from Banjarmasin City.
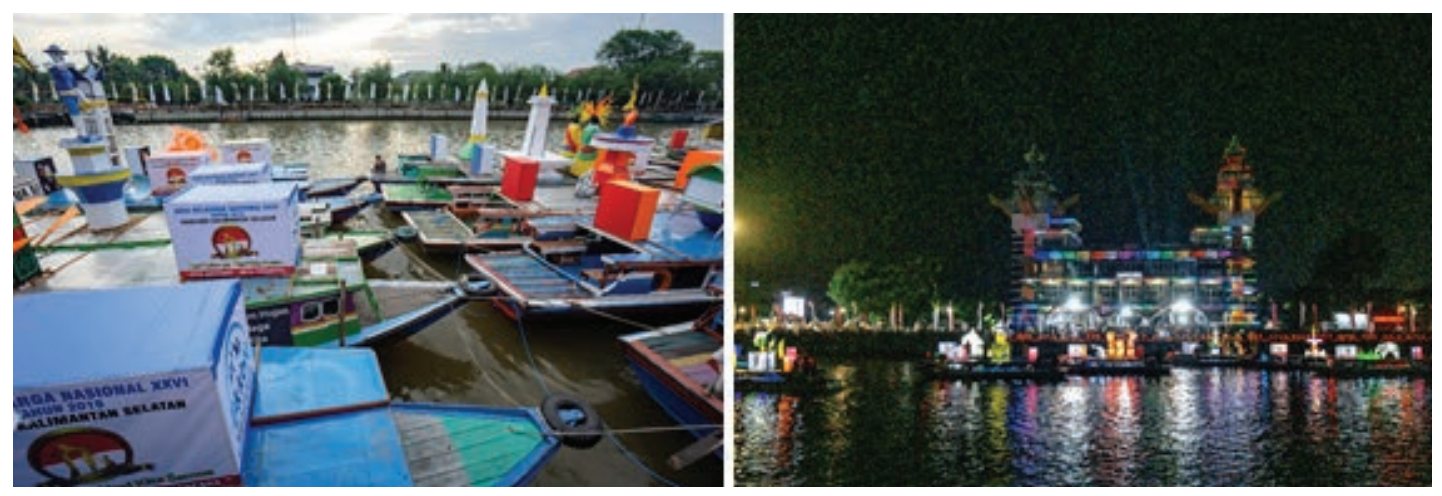

Figure 6: Festival of ornamental jukung in day and night. Source: private photos.

\subsection{Process}

The trading process in this floating market is very unique for visitors because of their transactions are done on the motorboat, where visitors' motorboat will soon be surrounded by the women traders' rowboat. To make them stable and hand in hand, the boats are equipped with hooks that can link the motorboat and the rowboat.

The traders can move swiftly in their rowboat. The body's balance becomes a counterweight to keep the rowboat stable. They use river flow and wooden paddles to control the speed of the rowboat.

The traders offer their products from their rowboat, invite visitors to choose what they like and wrap the chosen product in purun leaves. Often, they invite visitors who buy a large amount of their products to ride their boat for free. 
In addition to interactions between sellers and buyers, another activity that is not too visible is the trading activity between the women traders themselves. They do not necessarily buy and sell their own products, but often through barter, as done since hundreds of years ago.

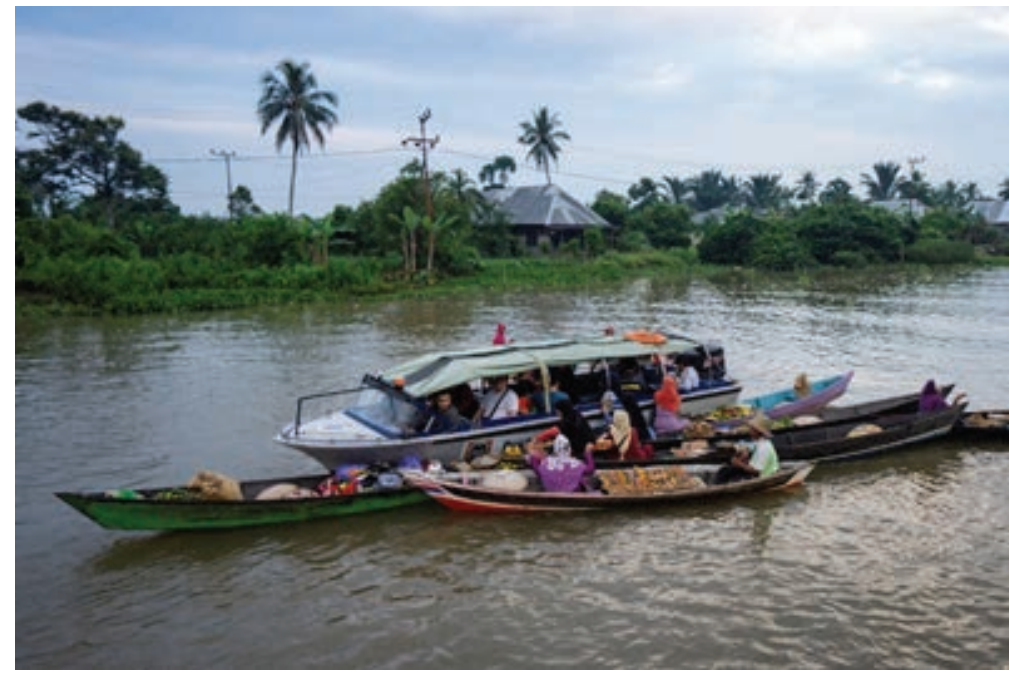

Figure 7: Transaction process between sellers and buyers at Lok Baintan floating market. Source: private photo.

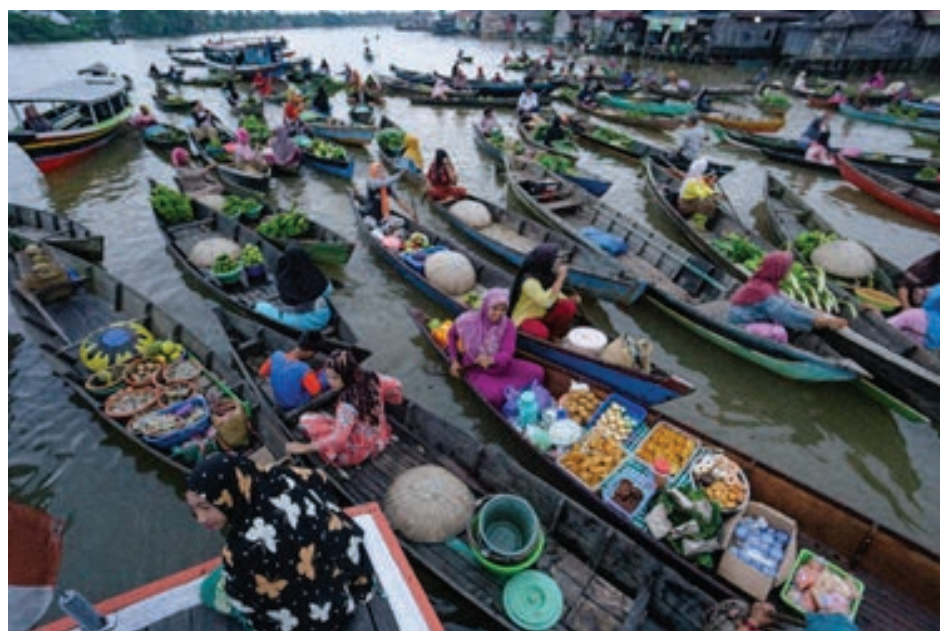

Figure 8: Sellers interaction at Lok Baintan floating market. Source: private photo.

\subsection{People}

Traders in the floating market are usually adult women or acil-acil in the Banjar language. The women, or acil-acil, wear a unique make up. They wear cold face powder for their face to prevent overheat. Their brownish face stands in contrast to their unevenlydistributed white and cold face powder. The sensation of cold face powder makes them comfortable in the morning heat. 
In addition to cold face powder, the women traders also wear wide purun straw hat. The hat protects them from the weather. Many of them use a kind of turban for the head with a unique thread. Most of the time, they wear clothes in bright colors with floral patterns.

The traders are mostly locals from Lok Baintan. Averagely, their husbands work in the fields as farmers or ranchers, while the women sell their products in floating market. The women are quite friendly to both local and international tourists who visit their place. They understand foreign languages enough to make transaction. As their custom, the traders usually sing when asked, and when the transaction is over they will immediately give a spontaneous, various rhyme to entertain their buyers. Not only that, if visitors buy a large amount of their products, they give additional service such as allowing the visitors to ride their boat and take photos for their Instagram content.
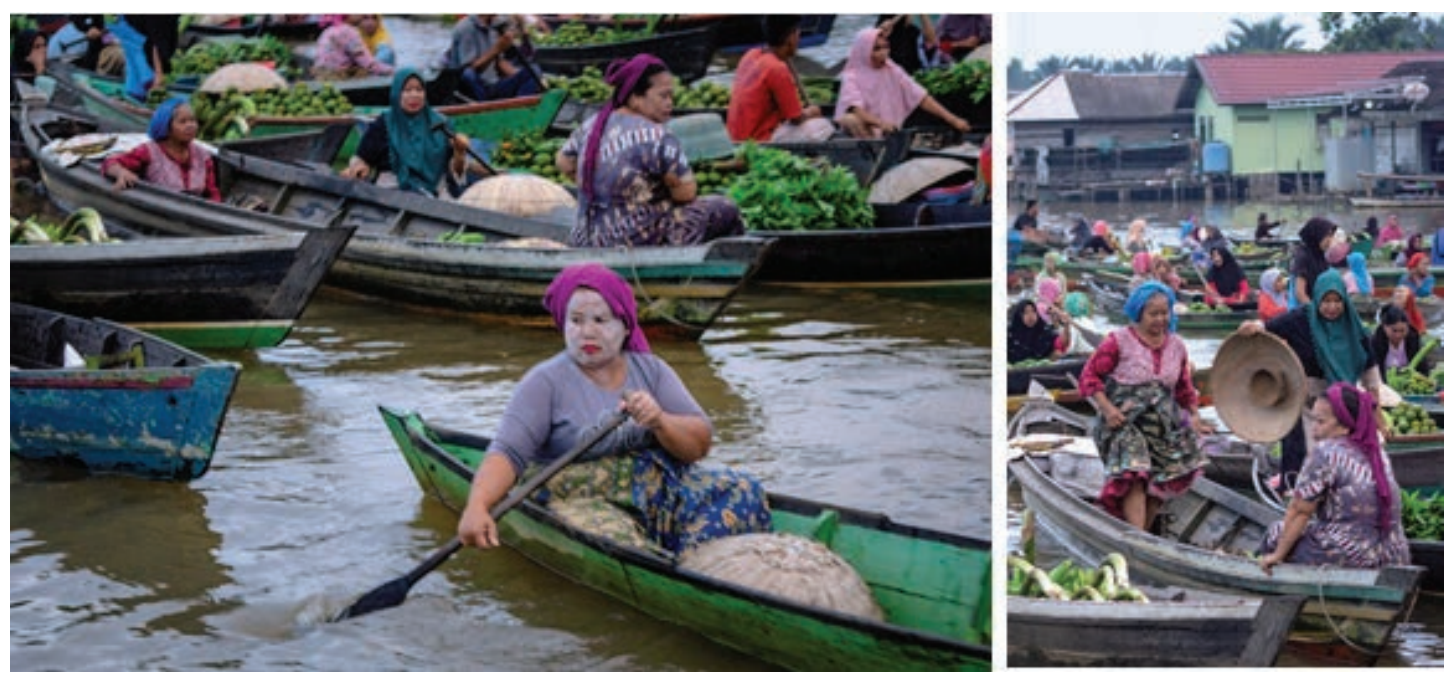

Figure 9: The unique characteristics of acil (pupur, caping purun and veil), sellers of Lok Baintan floating market. Source: privat photo.

\subsection{Physical Aspect}

The river is historically very important for Banjarmasin, which is famously known as the city of a thousand rivers. Since the 14th century, the river areas have become traffic routes for trade, especially during the formation of the Banjar Empire in 1595.

The Lok Baintan floating market starts its activities after dawn, precisely between 6 A.M. to 6.30 A.M., and gets quiet at 8.00 a.m. During its busy hours, the number of boats involved in the activities can reach 50 until 200. When there are lots of traders and ships can number between 50 and 200 traders, fill the river with their colorful boats and various products, water splash caused by motorboats and traders' paddles 
in their rowboats, and the distinctive smell of river water, the sound of motorbikes, the buzzing of traders' babbling, and the rise and fall of river ripples become an authentic experience for the visitors.

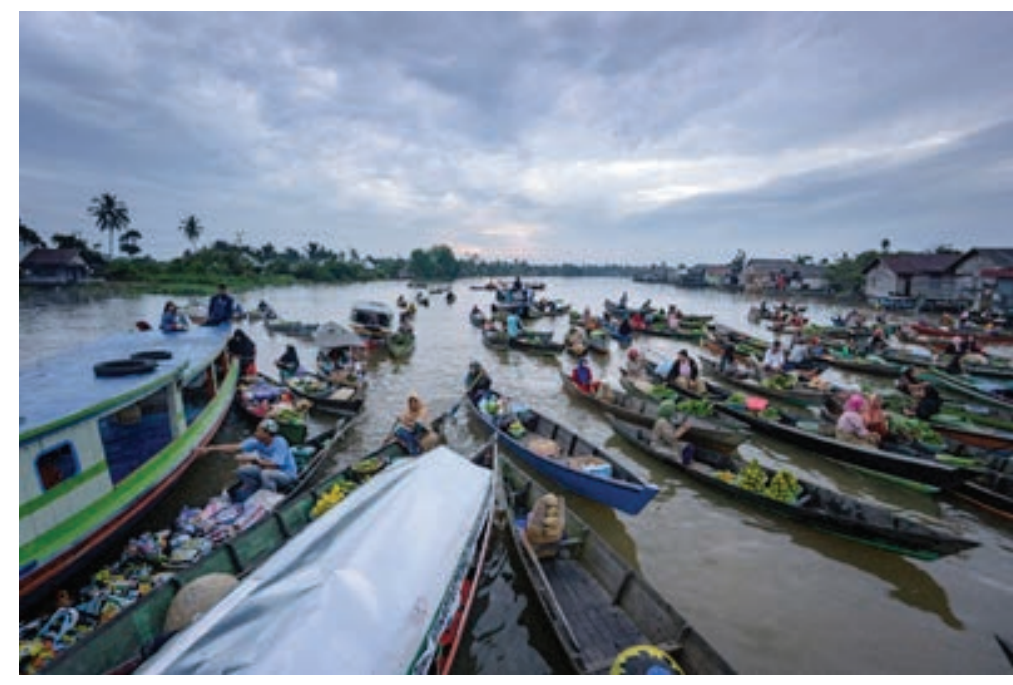

Figure 10: Crowd of Lok Baintan floating market. Source: private photo.

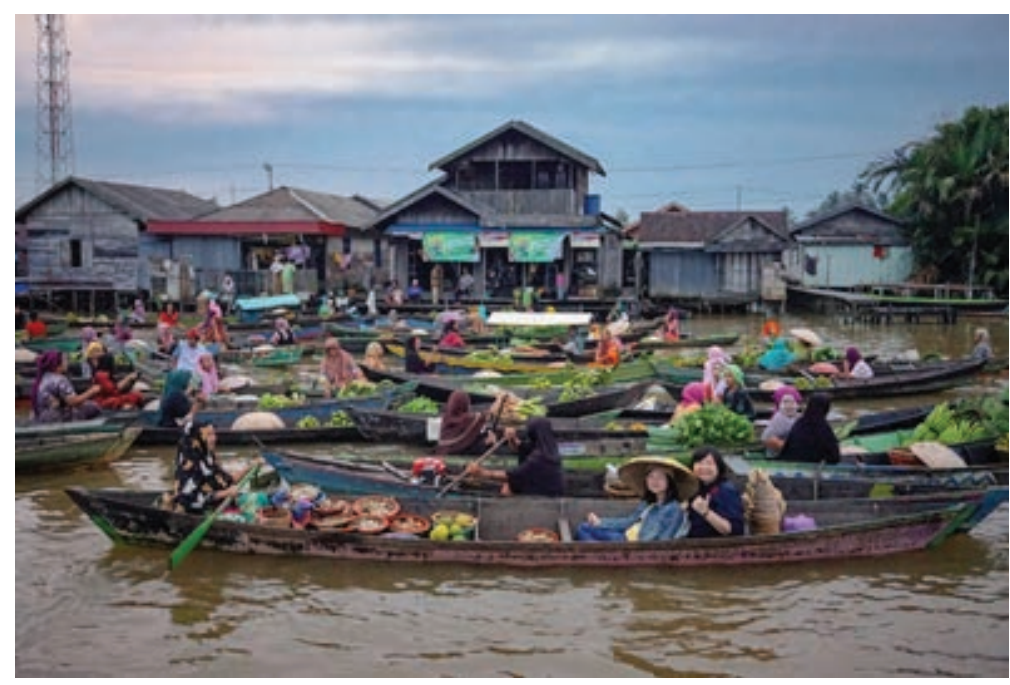

Figure 11: Jukung and Klotok as main transportation at Lok Baintan floating market. Source: private photo

\section{Discussion}

The discovery of marketing mix as explained in the previous sections was not planned. Some aspects occurred naturally, giving a very distinctive feeling. Regarding this, there are a number of significant things that need to be underlined based on the findings of this study: 
1. Elements of marketing mix in this area occurred simultaneously, either from visitors, manager or local government, and traders as a mutualism community.

2. The awareness that their community is a learning community. This community of women entrepreneurs can be developed more through events and their willingness to learn and try new activities.

3. The awareness to preserve natural conditions and strive for modernization at the same time serves as a good step for adaptation, both for developing tourism areas and preserving the community which leads to the preservation of the local sense of place and increased tourism.

\section{Conclusion}

Entrepreneurial community with its distinctive character in the Lok Baintan area, Martapura River, Banjarmasin, is not only as a product-based community but also servicebased community in marketing their products, including product uniqueness (unique commodities), price (price and bargaining processes), place (trading activities in river corridor), promotion (a unique way of promotion form both traders and government support), process (unique buying and selling process), people (traders' ethnic background, lifestyle and speech style), and physical aspects (buying and selling locations on motorboat which is unique and has memorable value).

This marketing effort was done naturally by an entrepreneurial community in the Lok Baitan, with simultaneous support from the local government, visitors, and mass media. This unique marketing process also shapes the distinctive and authentic atmosphere, as well as supports the sense of place of the Lok Baintan as a tourism area.

\section{Funding}

This research was funded by PTUPT Grants from Indonesian Ministry of Research, Technology in Higher Education (Kemenristekdikti) under the grant number 055/SP2H/LT/ MONO/L7/2019.

\section{Acknowledgment}

The authors also thanked those who have contributed in this study, especially to the local traders, Head of Lok Baintan community, Head of Tourism Office, Province of 
South Kalimantan and our research partners from Faculty of Geography and School of Architecture Universitas Lambung Mangkurat as well as to the LPPM Universitas Ciputra.

\section{Conflict of Interest}

The authors have no conflict of interest to declare.

\section{References}

[1] Fortunato, M. W-P., and Alter, T. R. (2011). The Individual-Institutional- Opportunity Nexus: An Integrated framework for analyzing entrepreneurship development. Entrepreneurship Research Journal, 1, 1: Article 6.

[2] Lyons, Thomas S., Alter, Theodore R., Audretsch, David., and Augustine, Darline (2012). Entrepreneurship and Community: The Next Frontier of Entrepreneurship Inquiry. Entrepreneurship Research Journal: Vol. 2: Iss. 1, Article 1.

[3] Kusumowidagdo, A., Kaihatu, T. S., Wardhani, D. K., Rahadiyanti, M., \& Swari, I. A. I. (2019). An Analysis of Sense of Place in Floating Market Lok Baitan, Kalimantan: a Study About Physical and Social Factors of Commercial Area in River Corridor. Penerbit Universitas Ciputra.

[4] Selsky, J. W. and Smith, A.E. (1994). "Community entrepreneurship: A frameworkforsocial changeleadership,"Leadership Quarterly,5,3-4: 277-296

[5] Haugh, H. M., \& Pardy, W. (1999). Community entrepreneurship in north east Scotland. International Journal of Entrepreneurial Behavior \& Research, 5(4), 163172.

[6] Wardhani, D. K., Kusumowidagdo, A., Kaihatu, T. S., \& Rahadiyanti, M. (2019). Sense Of Place Pasar Barang Antik Triwindu: Eksplorasi Faktor Fisik Dan Sosial Pada Kompleks Arsitektur Komersial Di Surakarta.

[7] Anjani, H. D., Irham, I., \& Waluyati, L. R. (2018) Relationship of 7P Marketing Mix and Consumers' Loyalty in Traditional Markets. Agro Ekonomi, 29(2), 261-273.

[8] Sungkyun Lee. (2017). A Study on Traditional Market Decline and Revitalization in Korea - Improving the Iksan Jungang Traditional Market -, Journal of Asian Architecture and Building Engineering, 16:3,455-462, DOI: 10.3130/jaabe.16.455

[9] Creswell, J. W. (2014). Research Design: Qualitative, Quantitative and Mixed Methods Approaches (4th ed.). Thousand Oaks, CA: Sage. 
[10] Harrington, R. J., Ottenbacher, M. C., \& Fauser, S. (2017). QSR brand value. International Journal of Contemporary Hospitality Management, 29(1), 551-- 570. https://doi.org/10.1108/JCHM-06-2015-0300 